The observational foatures of tensile, hardness, notched bar, wear, hysteresis and fatigue testing are well presented, with a text liberally garnished with tables of typical results by way of illustration. Fatigue, which is clearly close to the author's heart, receives a particularly generous coverage. A commendable feature is a chapter on the effects of overstrain in the early part of the tensile stress - strain curve, which, although known for at least fifty years, seldom finds its way into books of this kind. A realistic preference for proof stress rather than elastic limit permeates the text, along with a recognition of the importance of hysteresis. Those interested to learn more about the neglected factor of spurious energy loss in notched-bar testing, to which the author properly directs attention, would do well to consult reference I, which is given on p. $287 \mathrm{for}$ a different purpose.

The substantial section devoted to engineering resilience calculations, in the chapter on impact tests, appears a little out of place in this work, and the inclusion of notched-bar tests under the same general heading is misleading in view of the secondary importance of the rate of deformation here. In the interspersed sections of the text on interpretation of the tests, the author does not always get completely to grips with the problems. For example, no mention is made of Tabor's illuminating, but admittedly approximate, application of plane strain plasticity to the analysis of the hardness test; and the treatment of the yield point in iron and its associated recovery from overstrain would make more convincing reading if related to Cottrell's basically simple picture of solute atom migration.

Briefly, the book, which is handsomely printed and illustrated, gives a competent account of the experimental features of the mechanical properties of metals, but the senior and graduate student to whom the work is commended in the preface will probably find its attempts at interpretation inadequately stimulating.

K. M. ENTWISTLE

\section{GEOLOGY OF THE ICE AGE}

\section{Das Eiszeitalter}

Grundlinien einer Geologie des Quartärs. Von Dr. Paul Woldstedt. Erster Band : Die Allgemeinen Erscheinungen des Eiszeitalters. Zweite, völlig neu bearbeitete Auflage. Pp. vii + 374. (Stuttgart : Ferdinand Enke Verlag, 1954.) 41 D. marks.

THE study of Pleistocene deposits is often more

difficult than that of some older rocks because of the diversity of facies which is found. In dating Pleistocene beds it is therefore safer, where possible, to rely on more than one kind of 'zonal fossil'. In the present volume, as in past work, Prof. P. Woldstedt has proved himself to be a believer in this principle and shows an admirable all-round approach to the problems of the Ice Age. I understand from a statement at the end of the first chapter that this is only the first volume of a more comprehensive work and that a second is to be written dealing with separate regions.

After one introductory chapter, Chapters 2-9 are devoted to comparative glaciology : a full description is given of the world's existing ice-sheets, and depositional forms, including various linds of moraines, outwash gravels and loess, as well as the processes of erosion, are discussed as effects of the
Pleistocene ice-sheets. Interesting details are also given of the work by Milthers and others on the erratics carried by the various Baltic glaciers. The author's treatment of these subjects is in harmony with his long experience in the field, and the illustrations, some of which are exceptionally clear, are partly from his own photographs.

Prof. Woldstedt then turns his attention to fossil plants and animals, dealing at some length with the interglacial plant beds (Chapter 12) and tracing the evolutiun of the flora through the succession from the Reuverian up to the Holocene. Pollen diagrams are shown for the Cromer Forest Bed, which is considered to be Pre-Elster, also for the Elster-Saale and Last Interglacials in Northern and Central Europe, with detailed descriptions of the forest histories. No attention is paid to the plant remains at Hoxne, but now that this site has been freshly described by West and Donner, presumably it will bo included in the forthcoming second volume. Examples are also given (Chapter 10) of marine interglacial deposits. The Eem marine beds of Holland and Germany are placed in the Last Interglacial, and the earlier Holstein deposits in the Elster-Saale Interglacial ; and in Table 1, p. 215, the Holstein horizon is correlated with the Tyrrhonian, and the Eem with the Monastirian. This table summarizes the author's ideas on long-distance correlations and emphasizes a major problem which has been evident in his earlier publications, namely, tho difficulty of fitting in the three known glaciations of Northern Germany with the four (or five) recognized elsewhere.

Chapters 13 and 14 then summarize the kinds of fossil man and his implements, maintaining that the Heidelberg jaw and the earliest Pithecanthropus remains belong to the Gunz-Mindel Interglacial, and Peking man is placed with the Swanscombe and Steinheim fossils in the Mindel-Riss stage. The Fontéchevade and Ehringsdorf remains are placed with the Neanderthal man in the Last Interglacial. Dating of the Palæolithic implements is conventionally related to the Alpine glacial sequence.

The last three chapters (15-17) are given up to the problems of isostatic and eustatic changes of level, to a discussion of changes of climate and finally to a summary of the theories which have been formed to account for these changes. The theoretical aspect of these questions is sometimes overstressed, as in the discussion of eustatic changes of sea-level, and Fig. 121 on p. 294 represents these changes according to an ideal which does not entirely agree with the facts discovered by Gignoux, Deperet and later workers ; for example, the Sicilian stage is placed in an interglacial episode in spite of the fact that it has a notably cold fauna. Apart from some of these details, most interesting climatic reconstructions are attempted, one of the most successful showing the position of the ice-sheets, tree-line and temperate forests during the Last Glaciation (Fig. 129, p. 320). The discussion of the causes of climatic change is very detailed.

The list of references at the end is comprehonsive, considering the complexity of the subject, but certain omissions will perhaps be put right in the next volume; the main work of James Geikie, F.W. Harmer and Prof. P. G. H. Boswell, for example, receives little or no attention. In general, however, this book is particularly well indoxod and is a most useful and well-balanced introduction to a very intricate subject. D. F. W. BADEN-PoweLL 